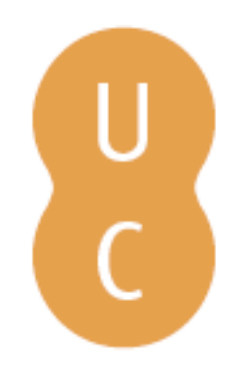

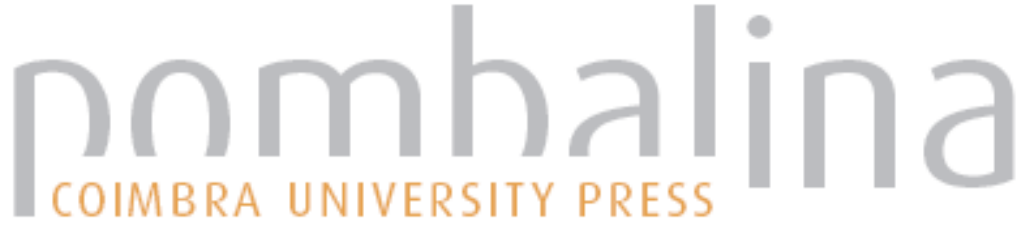

\section{O Vitélio de Suetónio: uma vida centrada na gula}
Autor(es): $\quad$ Brandão, José Luís Lopes
Publicado por: Imprensa da Universidade de Coimbra
URL
persistente: URI:http://hdl.handle.net/10316.2/45242
DOI: $\quad$ DOl:https://doi.org/10.14195/978-989-26-1720-6_2

Accessed : $\quad$ 26-Apr-2023 13:32:57

A navegação consulta e descarregamento dos títulos inseridos nas Bibliotecas Digitais UC Digitalis, UC Pombalina e UC Impactum, pressupõem a aceitação plena e sem reservas dos Termos e Condições de Uso destas Bibliotecas Digitais, disponíveis em https://digitalis.uc.pt/pt-pt/termos.

Conforme exposto nos referidos Termos e Condições de Uso, o descarregamento de títulos de acesso restrito requer uma licença válida de autorização devendo o utilizador aceder ao(s) documento(s) a partir de um endereço de IP da instituição detentora da supramencionada licença.

Ao utilizador é apenas permitido o descarregamento para uso pessoal, pelo que o emprego do(s) título(s) descarregado(s) para outro fim, designadamente comercial, carece de autorização do respetivo autor ou editor da obra.

Na medida em que todas as obras da UC Digitalis se encontram protegidas pelo Código do Direito de Autor e Direitos Conexos e demais legislação aplicável, toda a cópia, parcial ou total, deste documento, nos casos em que é legalmente admitida, deverá conter ou fazer-se acompanhar por este aviso.

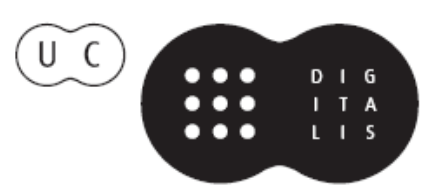


Carmen Soares

\section{Cilene da Silva Gomes Ribeiro}

\section{(coords.)}

MESAS

\section{ALIMENTAÇÃ O, SAÚDE \& CULTURA}

\section{IU LUO-BRASILEIRAS}

\section{VOLUME II}

IMPRENSA DA UNIVERSIDADE DE COIMBRA

COIMBRA UNIVERSITY PRESS

PUCPRESS 


\title{
O Vitélio de Suetónio: UMA VIDA CENTRADA NA GULA*
}

\author{
(The Vitellius of Suetonius: \\ a life centered in gluttony)
}

\author{
José Luís Lopes BRANDÃo \\ Universidade de Coimbra \\ Centro de Estudos Clássicos e Humanísticos \\ da Universidade de Coimbra \\ IOSEPHUS@FL.UC.PT
}

Resumo: As fontes antigas apresentam Vitélio como um gastrónomo e amante da boa mesa. Mas Suetónio, seguindo os objectivos da biografia, centrada por força do género sobre o carácter, e o seu método de organização por rubricas, constrói toda a Vida de Vitélio em volta do topos do seu principal vício - a gula -, fazendo com que toda a existência pública e privada do imperador fique fortemente determinada por aquela característica.

Palavras-chave: Suetónio, Vitélio, luxuria, gula, Império.

АвSTRACT: The ancient sources present Vitellius as a gourmet and lover of good food. But Suetonius, following the aims of the biography, centered on the character, according to the main characteristics of the biographical genre and his method of organization by rubrics, builds the entire Life of Vitellius around the topos of his main vice - gluttony - shaping all the public and private emperor's existence strongly determined by that characteristic.

Keywords: Suetonius, Vitellius, luxuria, gluttony, Empire.

A Vida de Vitélio aparece em Suetónio como o contraponto da biografia que a antecede - a de Otão, imperador que o biógrafo demonstra apreciar, provavelmente pelo facto de o seu pai ter sido oficial no exército daquele. Por isso se compreende que o biógrafo dos Césares tenha criado um retrato assaz negativo, dando excessivo crédito à propaganda dos Flávios contra o Vitélio:

"Trabalho desenvolvido no âmbito do projeto UID/ELT/00196/2013, financiado pela FCT - Fundação para a Ciência e a Tecnologia / Convénio FCT-CAPES - DIAITA. À colega e amiga Luísa Ferreira agradeço a leitura atenta e oportunas sugestões. Incorreções que subsistam são de minha responsabilidade. 
por comparação com os outros Césares, este imperador aparece descrito como o mais detestável de todos, desde o nascimento (ou até antes) até à morte. A gula, desdobrada no excesso de comida e de bebida, é o seu principal vício e parece ser a mãe de todos os vícios, até ao nível do repugnante.

A imagem estabelecida de Vitélio é acentuada pelo género. A biografia antiga distingue-se, como é sabido, da História por, segundo diz Plutarco na introdução à Vida de Alexandre, se concentrar sobretudo em iluminar o carácter ${ }^{1}$. Ora este efeito caracterológico ainda acaba por ser mais acentuado pelo método de Suetónio que, como é sabido, privilegia a descrição por rubricas (per species), como ilustração analítica de virtudes e vícios, vida pública e vida privada, em detrimento da descrição cronológica (per tempora), reservada habitualmente para o período da ascensão de um imperador até atingir o império. Além disso, o biógrafo dos Césares tende a resumir num parágrafo os feitos militares, enquanto se alonga a descrever hábitos, cultura, aspecto; em suma, questões relacionadas com os mores. Como resultado, tende a operar generalizações, transformando em hábitos comportamentos muitas vezes particulares e a organizar as matérias em crescendo de intensidade, em vez da ordem cronológica, potenciando assim o efeito sobre os leitores ${ }^{2}$.

\section{i. A fundamentação de um Cliché}

Toda esta Vida se organiza em volta do topos da gula, que se apresenta como um fio condutor estruturante na organização que Suetónio dá às rubricas habituais da biografia antiga. A rubrica dos antepassados, com que o biógrafo começa quase todas as Vidas, antecipa já em parte o comportamento de Vitélio, que Suetónio reporta no geral indigno. Neste caso, faz-nos saber que o tio homónimo do imperador, Aulo, era notável pela magnificentia da mesa sumptuária - perlautus no dizer de Suetónio, termo usado aqui e também na Vida de Nero, para referir os fulanos sumptuosos que este imperador admirava $^{3}$. Tendo em conta o método suetoniano e o conceito que os antigos tinham sobre o carácter, considerado imutável, trata-se certamente de busca de fundamentação do traço. Com efeito, o biógrafo costuma procurar nexos entre os imperadores e a sua "carga hereditária" ${ }^{4}$. De cariz semelhante é uma

\footnotetext{
Um pequeno gesto ou dito de espírito pode, segundo o Queronense (Alex.1.), ser mais determinante para compreender o ethos do que grandes feitos político-militares.

2 Neste trabalho, foi retomado, agora numa perspectiva gastronómica, material de Brandão 2009: passim; para uma síntese das características do modus scribendi de Suetónio, vide pp. 55-91.

Praelatus alioqui famosus cenarum magnificentia: Vit.2.2. Cf. Nero 30.1. A palavra é usada só por Suetónio. Cf. Venini 1997: 106.

${ }_{4}$ Cf. Tib. 3.1: ex hac stirpe Tiberius Caesar genus trahit, e<t> quidem utrumque; Nero 1.6: Pluris e familia cognosci referre arbitror, quo facilius appareat ita degenerasse a suorum uirtutibus
} 
anedota que a seguir se conta sobre o pai do imperador, Lúcio, que se teria deixado dominar pelo amor perinfamis ${ }^{5}$ de uma liberta, chegando a usar em público, como remédio para a garganta, a saliva dela misturada com $\mathrm{mel}^{6}$. Não se tratava de nada de anormal, pois o uso medicinal da saliva era comum ${ }^{7}$, mas Suetónio salienta o facto de fazer isso diariamente e à vista de todos ${ }^{8}$.

Uma outra ideia presente nesta Vida, relacionada com a indignidade, prende-se com o uso do termo sordida. E tal pecha está presente desde o início, nas duas versões sobre a origem da família: se uma versão, atribuída aos aduladores, considera a linhagem antiga e nobre, entroncada em Fauno, rei dos Aborígenes, e na divindade Vitélia (Vit. 1), outra, dos detractores, considera-a noua, obscura e mesmo sordida, porquanto remonta a um liberto, um sapateiro remendão, cujo filho, enriquecido à custa de bens confiscados e em processos do fisco, casou com uma prostituta. Mas embora o biógrafo finja distanciamento, sed quod discrepat, sit in medio (Vit. 2.1) («mas, neste desacordo, o melhor é que se fique em um ponto intermédio»), a verdade é que a pecha infamante ganhará relevância ao longo da biografia. Mais tarde se concluirá que a gula era sordida. Portanto, mesa farta e sordidez caminharão a par.

\section{O Destino E A GULA COMO AgENTES DA História}

O biógrafo apresenta uma figura vítima do destino, como demonstra a reacção dos pais ao conhecimento do horóscopo ${ }^{9}$, e marcada pela ignomínia desde tenra idade. A pecha de que passou a meninice e a primeira adolescência entre os supostos prostitutos de Tibério em Cápreas é duvidosa mas

Nero, ut tamen uitia cuiusque quasi tradita et ingenita ret< $<>$ ulerit. Para uma visão mais geral da rubrica dos antepassados de Vitélio, vide Brandão 2009: 337-338.

5 Adjectivo significativo por ser raro, pois, segundo Venini (1997: 109), não parece atestado antes de Suetónio.

Vit.2.4.

Como regista Plínio, Nat 28.35-39; 28.76; 28.193. Vide Murison 1992: 138.

Ne clam quidem aut raro sed cotidie ac palam.

Por conhecerem o horóscopo do recém-nascido, os progenitores horrorizaramse tanto que o pai se opõe a que lhe confiem uma província, e a mãe, ao saber que ele tinha sido enviado às legiões e proclamado imperador, lamentao como perdido. Vide análise da influência do destino nas Vidas dos Césares em Brandão 2009: 199-211. 
demolidora ${ }^{10}$; o mesmo se diga da suposição de que o seu pai teria subido na carreira corporis gratia do filho, o que não corresponderá de todo à verdade ${ }^{11}$.

Suetónio continua a sua tese com o veredicto de que: sequenti quoque aetate omnibus probris contaminatus («também na idade seguinte foi conspurcado por todo o género de opróbrios»), procurando associá-lo aos vícios dos outros Júlio-Cláudios: diz que obteve o favor de Gaio (Calígula) pela comum dedicação às corridas do circo; o favor de Cláudio, pela afeição aos jogo dos dados; o favor de Nero, pelas mesmas paixões e porque, ao presidir aos jogos Neronianos, secundara os que instavam o imperador a participar no concurso dos citaredos, o que Nero desejava, mas se não atrevia a fazer (Vit.4).Vitélio aparece, na versão de Suetónio, como uma síntese caricatural daqueles três imperadores, pelo excesso no que diz respeito à sumptuosidade.

O vício da gula, que perpassa por toda esta biografia, cruza-se com a força do destino quando, paradoxalmente, se transforma numa espécie de trampolim que garante o progresso na carreira das armas, e, em última análise, o acesso ao governo imperial. A atribuição, inesperada, como sugere o biógrafo (contra opinionem), de uma província é fundamentada com o testemunho do próprio imperador em exercício:

[...] nisi quod Galba prae se tulit nullos minus metuendos quam qui de solo uictu cogitarent, ac posse prouincialibus copiis profundam gulam eius expleri, ut cuiuis euidens sit contemptu magis quam gratia electum (Vit. 7.1).

“[...] se bem que Galba revelou claramente que ninguém era menos temível do que quem pensa só em comida, e que a goela dele sem fundo podia ser saciada com a abundância da província, pelo que se tornou claro para toda a gente que fora escolhido mais por desprezo que por favor" ${ }^{\prime 2}$.

10 Vit. 3.2. Esta informação é suspeita, tal como todos os rumores sobre a devassidão de Tibério em Cápreas. Se Vitélio (porque morreu com 59 anos: Vit. 18) nasceu em 12 d.C. (e não em 15, como Suetónio indica, talvez erradamente, por referência aos cônsules), já tinha dezanove anos em 31, ano a partir do qual datam as histórias escabrosas sobre Tibério, o que, como observa Murison (1987: 97-99), se não conforma exactamente com pueritiam primamque adulescentiam Capreis egit. Vide também o comentário de Murison 1992: 141-142.

11 Tácito, Hist.3.86.1, diz, pelo contrário, que Vitélio devia toda a sua ascensão aos méritos do pai. Para uma análise da carreira política de Vitélio antes de chegar ao império, vide Brandão 2009: 130-131.

12 Ideia semelhante vem expressa em Tácito (Hist.2.31.1), onde se sugere que as ignauae uoluptates ('os apetites indolentes') de Vitélio não eram causa de receio para o Estado, em comparação com os vícios de Otão, e se acrescenta que por causa do ventre e da gula Vitélio se desonrava a si próprio (Hist. 2.31.3: Vitellius uentre et gula si inhonestus). Segundo Díon Cássio (64.4.3), o próprio Nero se ria das predições que auguravam o império a Vitélio (e em que nem sequer o próprio acreditava) e não o considerava uma ameaça. 
Pode ser significativo que tal vício seja apontado e ampliado (profunda gula) por Galba, imperador que representou a tendência oposta e igualmente censurável para o biógrafo (que não partilha a admiração de Tácito): uma austeridade tal que lhe granjeou a fama de avaro ${ }^{13}$.

E o nexo de causalidade entre o carácter e o destino imperial continua. Graças à sua liberalidade, Vitélio foi recebido com entusiasmo por um exército desejoso de revolta. Precedeo a reputação de afável e generoso (facilis ac prodigus animus): durante a viagem, tratara os soldados com amabilidade e familiaridade, exemplificada com uma nota significativa dos temas mais frequentes desta Vida: questionava os viajantes se já tinham tomado o pequeno almoço e demonstrava com arrotos que ele próprio já o tinha feito (Vit.7.3). Deste modo, um traço à partida positivo, a comitas de Vitélio, também assinalada por Tácito (Hist.1.52.2), é rebaixada em Suetónio por associação aos temas estruturantes da gula e falta de dignidade no cargo ocupado.

O efeito de uma familiaridade, que hoje diríamos populista, acompanhada de relaxamento da disciplina militar, é uma cerimónia de aclamação precipitada, com total ausência de sentido de oportunidade, desordenada e farsesca. Em consonância com o anterior veredicto de Galba sobre a inércia de Vitélio, a aclamação deste apresenta-se em Suetónio tão passiva que recorda a de Cláudio, pela inversão de papéis e subjugação do protagonista à vontade da soldadesca ${ }^{14}$ :

Quare uixdum mense transacto, neque diei neque temporis ratione habita, ac iam uespere, subito a militibus e cubiculo raptus, ita ut erat in ueste domestica, imperator est consalutatus circumlatusque per celeberrimos uicos, strictum Diui Iuli [i] gladium tenens detractum delubro Martis atque in prima gratulatione porrectum sibi a quodam (Vit. 8.1).

"Pelo que, mal passou um mês, sem se ter em conta nem o dia nem o momento, e já ao anoitecer, foi subitamente arrebatado do quarto pelos soldados, assim mesmo como estava, em roupa de trazer por casa, foi saudado imperador e levado pelas ruas mais concorridas, empunhando a espada do divino Júlio, que fora subtraída a um santuário de Marte e que um deles lhe tinha apresentado às primeiras felicitações"15.

13 Cf. Suet. Gal. 12.

14 Vide Martin 1991: 229-230.

15 Poulle (1997: 248) sugere que, simbolicamente, contra o punhal do "cesaricida" Galba, Vitélio levanta agora a espada vingadora do próprio Júlio César. Segundo este autor, os partidários de Vitélio compreenderam a alusão de Galba ao colocar o punhal ao peito ( $\mathrm{Gal}$.11). Os legionários faziam alusão à vingança exercida sobre Cássio e Bruto e à conquista da Gália, pois foram estas legiões da Germânia que, como as de César, venceram os Gauleses e Víndex. Plutarco (Caes. 26.8) diz que uma estátua subtraída a César estava depositada num santuário dos Arvernos e que o próprio César, quando soube, se recusou a retirá-la. Vide Brandão 2009: 150-155. 
O texto sugere que Vitélio não estava a contar com a aclamação e que a iniciativa foi toda dos soldados. Mas, se compararmos com as versões de Tácito e Plutarco verificamos que o episódio não foi assim tão imprevisto ${ }^{16}$, nem a atitude do aclamado tão passiva ${ }^{17}$.

De regresso ao pretório, ao ver o triclínio em chamas, como todos ficaram ansiosos perante o presságio adverso, Vitélio dá a sua própria interpretação: 'Bono', inquit, 'animo estote! Nobis adluxit"18 ("Animemse! - exclamou ele - Fezse luz para nós!»). Como Júlio César, também Vitélio procura voltar os presságios a seu favor. Suetónio conclui assim a rubrica sem comentar ${ }^{19}$, mas, para alguém que prima pela gula, parece significativamente pressago que encontre o triclínio em chamas. Se podemos ver o triclínio como metonímia da gula de Vitélio, parece haver, no momento significativo da aclamação, uma antecipação do castigo daquele vício, representado mais tarde, de forma explícita, no relato da morte.

Tendo em conta a importância que os presságios assumem na biografia de Suetónio, Vitélio é o mais desfavorecido pelos deuses. O avanço a caminho de Roma é malfadado desde o início e entre outros presságios ${ }^{20}$ destaca-se o de Viena: quando exercia a justiça, um galo saltoulhe para o ombro e depois para a cabeça. O improvável acontecimento, cujo significado ficará em suspenso até ao final da biografia, é mais um sinal de falta de dignitas, mas parece também querer sugerir, segundo Murison (1992: 152), que o imperador estava alcoolizado em serviço, como sugere Tácito ${ }^{21}$. Tais presságios são o símbolo da ineptidão de Vitélio como acrescenta o biógrafo (Vit. 9): Quibus ostentis par respondit exitus; nam confirmatum per legatos suos imperium per se retinere non potuit («a estes sinais ominosos respondem iguais resultados: com efeito, o império, que lhe foi garantido pelos legados, por si próprio não foi capaz de o manter»).

16 Suetónio, para acentuar a espontaneidade da aclamação, condensa os vários passos da revolta presentes em Tácito, Hist. 1.55-57 e Plutarco, Gal. 22. Ao desmembrar a narrativa entre as biografias de Galba (Gal.16.2) e Vitélio, silencia o contributo decisivo da armada de Germânia Superior (cf. Gascou 1984: 423) e só a seguir menciona a adesão desta à revolta (Vit. 8.2), como se entrasse pela primeira vez em contacto com Vitélio. Vide Murison 1992: 149-150.

17 Venini (1974: 997-2000) nota que, em Tácito e Plutarco (cf. n. anterior), há duas directrizes: uma do exército e outra de Vitélio. Em Tácito, a aclamação é precedida da inicitiva de Vitélio que envia mensagens revolucionárias às legiões. Também em Plutarco, Vitélio considera a possibilidade de assumir o poder antes da iniciativa de Valente, que o vem saudar como imperador. Ora em Suetónio há apenas uma directriz, que (ao contrário da aclamação de Galba) parte de baixo (do exército) para cima. Vide Venini 1977: 118-120.

$\begin{array}{ll}18 & \text { Vit. 8.2. } \\ 19 & \text { Vide Damon 2014: 49-50. }\end{array}$

20 Quando o grupo que Vitélio comandava se pôs a caminho, as suas estátuas equestres ruíram, a coroa, que colocara religiosissime, caiu em um regato.

${ }^{21}$ Hist. 3.56.2. Para este autor, o principal presságio era o próprio Vitélio: ignorante na arte militar, desprovido de capacidade de decisão, mostrava o medo e deixavase ver ébrio. 
Essa incapacidade manifesta-se desde logo no excesso do avanço para Roma (inter profusissimos absoniorum apparatus) e na indisciplina que permitia aos soldados a quem não bastavam os banquetes oferecidos, mas que progrediam para a rapina e para a violência ${ }^{22}$. Ele próprio agrava a sua maldição com atitudes ímpias ao chegar ao campo de batalha Betríaco, junto de Cremona, onde as suas tropas tinham derrotado as de Otão, que entretanto se suicidara para de forma altruísta evitar o prolongamento da guerra civil.

Vtque campos, in quibus pugnatum est, adit, abhorrentis quosdam cadauerum tabem detestabili noce confirmare ausus est, 'optime olere occisum hostem et melius ciuem'. Nec eo setius ad leniendam grauitatem odoris plurimum meri propalam hausit passimque diuisit. Pari uanitate atque insolentia lapidem memoriae Othonis inscriptum intuens 'dignum eo Mausoleo' ait, pugionemque, quo is se occiderat, in Agrippinensem coloniam misit Marti dedicandum. In Appennini quidem iugis etiam peruigilium egit (Vit. 10.3).

“Quando chegou aos campos onde se travara o combate, ousou encorajar
os que se afastavam dos cadáveres em decomposição com estas palavras
execráveis: 'muito bem cheira um inimigo morto, e ainda melhor se for
um cidadão'. E, facto não menos grave, para abrandar a violência do odor,
bebeu bastante vinho puro, à vista de todos, e distribuiuo em redor. Com a
mesma jactância e insolência, ao olhar a lápide escrita à memória de Otão,
disse que 'ele era digno de tal mausoléu'; e o punhal, com que o antecessor
se tinha matado, enviouo para Colónia Agripinense, para ser dedicado a
Marte. E no cume dos Apeninos fez mesmo uma festa nocturna”.

A nota de que bebeu vinho puro (plurimum meri) é, mais uma vez, a adequação do comportamento do biografado ao cliché da uinulentia, como nota Venini (1977: 125), mas também se adequa à ideia, que figura mais à frente, de que a gula não tem sentido de oportunidade (Vit.13.2). Tácito, que também descreve a cena, não refere tal impiedade ${ }^{23}$. Mas há mais: já Nero fora censurado por beber na presença do cadáver da mãe (Nero 34.4) - facto que não passaria despercebido a um leitor atento de Suetónio. O gesto de Vitélio contra a pátria faz ainda lembrar ditos atribuídos a César em contexto semelhante, depois da batalha de Farsalo ${ }^{24}$. São atitudes de bybris que fazem esperar um fim trágico. A par da gula cresce, pois, a arrogância, verificável nos actos de uanitas e insolentia perante a memória de Otão. A menção do punhal evoca a pietas erga patriam de Otão, que se suicida para pôr fim à

22 Vide Ornellas e Castro 2011: 391-392.

23 Tácito, Hist. 2.70, descreve a cena macabra sem mencionar as palavras ímpias, o gesto de beber ou a dedicação do punhal, embora note o contraste entre a atitude dos que choravam e a atitude prazenteira do imperador: At non Vitellius flexit oculos nec tot milia insepultorum ciuium exhorruit: laetus ultro et tam propinquae sortis ignarus instaurabat sacrum dis loci.

24 Cf. Suet.Jul. 30; Plu. Caes. 46.1. 
guerra civil, por contraste com a atitude ímpia de Vitélio. A festa nocturna sugere a indisciplina: o termo usado, peruigilia, adequirira um tom licencioso, como se percebe em Tácito (Hist. 2.68.1) ${ }^{25}$.

De resto a caminhada até Roma é sacrílega a todos os títulos, o que leva o biógrafo a sentenciar que Vitélio entra em Roma magis deinde ac magis omni diuino bumanoque iure neglecto («desprezando cada vez mais todas as leis divinas e humanas» ${ }^{26}$. Por detrás estão obviamente topoi da retórica contra a tirania (como parece sugerir a perpetuidade do consulado que ele assume).

\section{Glosando o mote: a gula no poder}

Há uma conexão estabelecida claramente com o último dos Júlio-Cláudios, que se tornara um estereótipo de extravagância: dá uma indicação clara sobre o modelo de governo a seguir (exemplar regendae rei p.), oferece no campo de Marte um sacrifício oficial aos Manes de $\mathrm{Nero}^{27}$ e pede a um citaredo que, num banquete solene, cante uma composição da autoria daquele imperador, demonstrando que era genuíno o seu entusiasmo pela actuação de Nero (Vit. 4). Relevante para a comparação será o facto de administrar o império segundo a vontade dos mais vis histriões e aurigas ${ }^{28}$, bem como a relação com o liberto Asiático ${ }^{29}$. Salta a vista o contraste com a luxuria da corte imperial na nota de que este liberto foi resgatado quando vendia posca, uma mistura de água e vinagre, consumida sobretudo por gente pobre e soldados ${ }^{30}$.

O estereótipo estava criado. De resto, Nero, tal como Calígula, servirá para caracterizar outros imperadores de má memória, como se vê por Domiciano,

25 Calígula tinha programado uma festa deste género (pervigilum) para o dia em que foi assassinado. Suet. Cal. 54.2.

26 Suetónio acentua a ilegalidade da entrada na cidade com armas à vista: Vit.11.1. Uma versão mais próxima da legalidade é apresentada em Tácito, Hist.2.89.1: Vitélio, que se dispunha a entrar na cidade paludatus accintusque, deixase convencer pelos amigos a vestir a praetexta, e os oficiais levam uma veste branca, enquanto em Suetónio envergam o sagum, hábito de guerra contraposto à toga. Vide Venini 1977: 125-126.

27 Vit. 11.2: et ne cui dubium foret, quod exemplar regendae rei p. eligeret, medio Martio campo adbibita publicorum sacerdotum frequentia inferias Neroni dedit.. Tácito (Hist. 2.95.1) refere o facto, mas não sugere que era "para que não houvesse dúvidas sobre o modelo de governo". Díon Cássio (65.7.3) assinala o desejo de imitar Nero, o sacrifício aos Manes do defunto e um gasto de grande soma de dinheiro, que causa alegria a uns e lamentos a outros.

${ }_{28}$ Exagero e vituperação de Suetónio a partir da anterior ligação de Vitélio a tais artistas, o que fez com que eles afluíssem a Roma (cf. Tac. Hist.2.71). A verdade é que Vitélio até atribuiu a cavaleiros funções que antes eram delegadas em libertos (cf. Tac. Hist. 1.58.1). Vide Murison 1992: 158-159; Venini 1977: 128.

29 Uma ligação picaresca, digna do Satyricon, como nota Martin (1991: 167 e 288-289), e que nos faria sorrir, se o liberto não fosse o principal conselheiro de Vitélio.

30 Cf. Plaut. Truc. 610. Vide Venini 1997: 128; André 1981: 172-3. 
mas também por Cómodo e Heliogábalo na História Augusta ${ }^{31}$. De acordo com o método habitual por rubricas, o biógrafo passa a sistematizar os vícios principais, a luxuria e a saeuitia (Vit. 13.1.) com exempla sugestivos. A luxúria concretizase na gula, vício no qual ele manifesta a sua falta de moderação, como já se viu ${ }^{32}$. Alega-se que fazia um banquete de cada uma das refeições do dia e aguentava-se, graças ao recurso ao vómito, como já fazia Cláudio ${ }^{33}$. Como se contava de Nero (Nero 27.3), também Vitélio exigia jantares a várias pessoas num só dia e impunha pratos dispendiosos aos anfitriões. Os seus jantares tornam-no o "imperador dos gastrónomos", como o classifica Dalby (2001: 74):

Famosissima super ceteras fuit cena data ei adventicia a fratre, in qua duo milia lectissimorum piscium, septem avium apposita traduntur. Hanc quoque exsuperavit ipse dedicatione patinae, quam ob immensam magnitudinem cli-

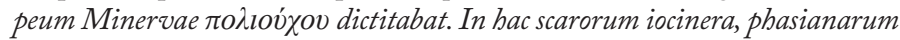
et pavorum cerebella, linguas phoenicopterum, murenarum lactes a Parthia usque fretoque Hispanico per navarchos ac triremes petitarum commiscuit. ${ }^{34}$

"O mais famoso de todos foi o banquete que, à sua chegada, lhe foi oferecido pelo irmão. Neste consta que foram servidos dois mil peixes seleccionadíssimos e sete mil aves. Também este ele próprio o superou com a oferta de uma bandeja que, dada a sua descomunal amplitude, proclamava 'escudo de Minerva protectora da cidade!'. Neste entremeou fígados de escaro, miolos de faisão e pavão, línguas de flamingo, intestinos de moreia, mandados trazer pelos comandantes e trirremes desde a Pártia até ao estreito de Gilbraltar".

Salienta-se a sumptuosidade, com pratos enormes e requintados, e o refinamento das iguarias transportadas, através do meios do Estado, desde os extremos do império ${ }^{35}$; um elenco quase pictórico de espécies com muitos paralelos na literatura latina - particularmente na diatribe contra a luxuria-, e nas artes figurativas ao longo da história de Roma ${ }^{36}$. Plínio (Nat.35.163ss) diz que o prato custou um milhão de sestércios; e Díon Cássio (65.3.3) diz que a bandeja era de prata e que perdurou até ao tempo de Adriano. O requinte reside no facto de tratar apenas partes muito específicas dos animais

Vide Brandão 2007: 133-145.

Vício que também era superlativado por Cláudio ( $C l$.33.1).

Suet. Cl.33.1.

Vit. 13.2. Cf. D.C. 65.2.2-3.2.

E de fora dele, acrescenta Díon Cássio (65.3.1), talvez referindo-se à Índia. Dalby (2001: 71-74) prefere a hipótese de que Díon Cássio se refira ao transporte de ostras da Britânia, que teriam já sido introduzidas em Roma antes de Vitélio; talvez no tempo de Nero (Cf.Juv. 4.136-142).

36 Vide D'Arms 2004: 428-450. 
(fígados, miolos, línguas ${ }^{37}$ ), de peixes e aves, símbolo da boa mesa, do valor dos animais, e do seu exotismo. Já Séneca (Ep. 89.22) vituperara a voracidade que faz capturar os animais por terra e por mar, para depois só se aproveitar uma ínfima parte de tal devastação ${ }^{38}$.

Com efeito, do escaro (ou sargo; a identificação é ambígua entre os autores modernos) eram apreciadas apenas as entranhas. Vitélio, servindo o fígado, parece inspirar a Marcial, que nos Xenia (13.84) diz que este peixe já vem corroído pelas ondas do mar; que tem apetitosas as entranhas, mas que o resto é de fraco sabor ${ }^{39}$. Era, pois, iguaria de primeira qualidade na época (Plin. Nat. 9.62; Petr. 93.6). Inicialmente só era pescado no Mediterrâneo Oriental e na Sicília, mas foi propositadamente introduzido no tempo de Cláudio entre Óstia e a Campânia, com a proibição de não o pescarem durante 5 anos, pelo que depois se disseminou ${ }^{40}$.

Quanto às aves, o faisão, embora já bem presente na boa mesa de $\mathrm{Roma}^{41}$, faz eco no nome à origem exótica - sendo originário da Cólquida, tira o nome do rio Fásis - como nota o poeta Marcial (13.72) com erudição: Argoa primum sum transportata carina./ Ante mibi notum nil nisi Phasis erat. ( A nau Argo foi a primeira a transportarme. Antes disso, nada conhecia além do Fásis») ${ }^{42}$. Quanto ao pavão, é um prato luxuoso que na literatura representa o sacrifício da beleza aos requintes do ventre: o poeta Marcial (13.70), contemporâneo dos factos, lamenta nos Xenia a crueldade da entrega ao cozinheiro de uma tão admirável ave ${ }^{43}$. O flamingo (13.71) era, tal como

37 Díon Cássio, no passo citado, salienta precisamente o facto de se tratar de línguas, miolos e fígados de certos peixes e aves.

38 Ad vos deinde transeo quorum profunda et insatiabilis gula hinc maria scrutatur, hinc terras, alia hamis, alia laqueis, alia retium variis generibus cum magno labore persequitur: nullis animalibus nisi ex fastidio pax est. Quantulum [est] ex istis epulis [quae] per tot comparatis manus fesso voluptatibus ore libatis? quantulum ex ista fera periculose capta dominus crudus ac nauseans gustat? quantulum ex tot conchyliis tam longe advectis per istum stomachum inexplebilem labitur? Infelices, ecquid intellegitis maiorem vos famem habere quam ventrem?

39 Hic scarus, aequoreis qui venit adesus ab undis, / visceribus bonus est, cetera vile sapit. Vide Venini 1977: 130.

$40 \quad$ Cf. Plin. Nat. 9.62-63; Macr. 3.16.10. Vide André 1981: 101-102; Leary 2001: 144.

41 O faisão aparece emparelhado em várias referências com as galinhas da Numídia (ou galinhas d'Angola), por Plínio (Nat.10.132) e por Marcial: neste poeta as duas aves figuram na longa ekphrasis da quinta de Basso (3.58.15-16), são elementos de um banquete de bom gosto (3.77.4) e um presente ideal nos Xenia (13.45). Nesta última colectânea as duas aves são depois tratadas individualmente em dois epigramas sucessivos (13.72 e 73).

${ }_{42}$ Trad. de Delfim Leão.

43 Também Horácio (Sat. 2.23-29) se interroga porque comer um animal cuja verdadeira beleza é bem melhor que o sabor ilusório, não superior ao de uma galinha. Plínio (Nat. 10.45), Varrão (R. 3.6) e Macróbio (3.13.1) dizem que o orador Hortênsio foi o primeiro a servir pavão num banquete inaugural. A partir daí torna-se um prato de luxo. Apício fala de isicia "uma espécie de almôndega” de pavão (2.53-54). Vide André 1981: 131-132; Leary 2001: 126. 
o pavão, criado em cativeiro ${ }^{44}$. Só aparece na mesa já no Império. A língua era considerada algo de requintado sabor segundo Plínio (Nat.10.133), um luxo censurado por Séneca (Ep.110.12), mas um belo presente das saturnais para Marcial (13.71): Dat mibi pinna rubens nomen, sed lingua gulosis/ nostra sapit. Quid si garrula lingua foret? («O nome dámo a pena rubra, mas a minha língua é uma delícia/ para gulosos. Que seria se a língua pudesse falar?») ${ }^{45}$.

Por fim aparece de novo um peixe de requinte: a moreia. Embora criadas também em viveiro, eram particularmente apreciadas as da Sicília, designadas por flutae $e^{46}$, gosto reflectido nos Xenia de Marcial (13.80) ${ }^{47}$. Eram servidas grelhadas ou cozidas (Apic. 10.449-454).

Portanto, nesta parte, a gula de Vitélio é caracterizada pela sumptuosidade da boa mesa, como seria de esperar. Também Díon Cássio (65.3.1) dirá mais tarde que o principado de Vitélio não foi senão orgias e divertimentos e que diversos bolos e pratos eram denominados a partir do nome do imperador 48 . Mas, de seguida, Suetónio retoma o topos da indignidade. E a rubrica atinge o clímax com a sordidez do comportamento do imperador:

Ut autem homo non profundae modo sed intempestivae quoque ac sordidae gulae, ne in sacrificio quidem umquam aut itinere ullo temperavit, quin inter altaria ibidem statim viscus et farris panes paene rapta e foco manderet circaque viarum popinas fumantia obsonia vel pridiana atque semesa.

"Era um tipo não só de uma goela sem fundo, mas também despropositada e abjecta, pelo que nem sequer se moderava durante sacrifícios ou viagens, que não mastigasse, ali mesmo entre os altares, as carnes e os bolos sagrados arrebatados ao fogo e, pelas tabernas das estradas, iguarias ainda fumegantes, ou mesmo do dia anterior e meias consumidas" ${ }^{\prime 9}$.

O motivo da profunda gula, já referido atrás pelas palavras de Galba (Vit. 7.1) corresponde a um lugar-comum ${ }^{50}$, aqui retomado e agravado com a classificação de intempestiva e sordida. Com tal voracidade, Vitélio parece aproximarse do tipo cómico do parasita da palliata, mas o facto de estar à cabeça do Império gera um efeito que, como acontece com Cláudio, vai além do cómico. Torna-se como que um parasita de Roma e de todo o Império.

44 Marcial inclui estas duas aves na ekphrasis da quinta de Faustino: 3.58.13-14. Vide Leary 2001: 127.

${ }_{45}$ Trad. de Delfim Leão. Heliogábalo, já no século III, manda servir miolos aos cortesãos segundo a História Augusta (SHA, Elag. 20). Vide André 1981: 124.

${ }_{46}$ Cf. Varr. R. 2.6.3; Plin. Nat. 9.169; Juv. 5.99; Macr. 3.15.7-8.

47 Vide André 1981: 100; Leary 2001: 139-140.

48 Martin (1991: 115-117) considera o retrato provavelmente verdadeiro.

49 Vit. 13.3. Vide Martin 1991: 115.

50 Cf. o já referido texto de Sen.Ep. 89.22. 
Depois Suetónio passa a ilustrar a saeuitia - termo associado na origem aos animais selvagens (vício principal dos típicos tiranos retóricos) ${ }^{51}$. Uma crueldade que, à semelhança da de Nero, é despropositada e arbitrária ${ }^{52}$, certamente um exagero do biógrafo ${ }^{53}$. Este conta que, a um doente que, durante um acesso de febre, lhe pedia de beber, o próprio Vitélio deu veneno num copo de água fria ${ }^{54}$. A outra vítima, depois de a condenar, manda reconduzila de novo à sua presença e, quando todos celebravam já a sua clemência, ordena que a matem à sua frente, porque 'uelle se' dicens 'pascere oculos' (Vit.14.2) «queria dar alimento aos olhos». Usando a habitual generalização, Suetónio transforma, aparentemente, uma vítima em várias ${ }^{55}$, e reforça a sua organização sistemática gula-saeuitia ${ }^{56}$, aproveitando uma sugestão de amálgama humorística entre a crueldade e voracidade que já existiria na propaganda contra Vitélio: de facto, aquele dito do imperador é referido por Tácito como justificação de Vitélio para a visita a um inimigo doente (Tac. Hist.3.39.1). A noção de gula é assim habilmente amplificada também no sentido da avidez de sangue. E a semelhança com Nero vai até ao matricídio. Só Suetónio faz recair sobre Vitélio a suspeição de responsabilidade na morte da mãe, e, paradoxalmente, por lhe ter negado alimento durante uma enfermidade ou por, a pedido dela, lhe ter facultado prontamente veneno ${ }^{57}$.

\section{Morte de Vitélio: o castigo da gula}

Nas lutas em Roma com os partidários dos Flávios, Vitélio é acusado pelo biógrafo de incendiar o templo de Júpiter (Vit.15.3), facto que resulta mais

51 Dunkle (1971: 14-15) nota que, a partir dos últimos anos de Cícero, o termo crudelitas começa a ser substituído por saeuitia na descrição popular do tirano. Acrescenta que o último implica conotações de histerismo e sadismo maníaco, uma vez que primariamente se refere à ferocidade dos animais selvagens. Em Suetónio, prevalece saeuitia. Vide Tabacco 1985: 89-116; Brandão 2008: 115-137.

52 A saeuitia é tal que, pelas semelhanças verbais, corresponde ao grau mais elevado de Nero: é exercida contra quem quer que seja e a qualquer pretexto. Vit.14.1: Pronus uero ad cuiuscumque et quacumque de causa necem atque supplicium; cf. Nero 37.1: Nullus posthac adhibitus dilectus aut modus interimendi quoscumque libuisset quacumque de causa.

53 Contra Suetónio, Díon Cássio, 66.6.2, afirma que Vitélio suprimiu reduzido número de otonianos.

54 Vit.14.1. Parece tratar-se também de um lugar-comum, uma vez que assim consta que foi assassinado Britânico: cf. Tac. Ann. 13.16. Vide Venini 1977: 132.

55 Suetónio parece desdobrar informações retiradas de uma mesma história, distribuídas em gradação ao longo da rubrica, com se tratasse de pessoas diferentes. Ora a comparação com Tácito parece indicar a utilização de elementos da narrativa da morte de Júnio Bleso: cf. Tac. Hist. 3.39.1. Vide Murison 1992: 162-163.

56 Para uma síntese dos passos de Suetónio onde se estabelece a ligação entre violência e comida, vide Damon 2014: 55.

57 Vit. 14.5. Tácito (Hist. 3.67.2) fala de uma morte providencial (opportuna mors), que, ocorrendo pouco antes da do filho, a poupou de assistir à aniquilação da família. Vide Cizek 1977: 132-133; Brandão 2009: 85-91 e 238-239. 
evidente pela técnica habitual de concentração dos factos sobre o protagonista da biografia ${ }^{58}$, além do possível efeito da propaganda flávia. A ligação entre impiedade e gula volta de novo na acusação de que contempla a refrega e o incêndio a partir do palácio de Tibério, no meio de um banquete (inter epulas). Salta aos olhos a semelhança com Nero na autoria e na contemplação do incêndio. Diverge a acção, coerente com as preferências de cada um: Nero canta e toca, Vitélio come ${ }^{59}$.

Por fim, salientam-se atitudes indignas de fuga desesperada face à aproximação do inimigo: foge para o Aventino, escondido numa liteira; e Suetónio não resiste à nota de que tinha por única e significativa companhia um padeiro e um cozinheiro - mantém até ao fim a característica de imperador gastrónomo ${ }^{60}$. Depois o retorno ao palácio deserto e a ocultação na pequena cela do porteiro ${ }^{61}$. A narrativa do linchamento popular, descrita também pelas outras fontes, é, em Suetónio, particularmente aviltante:

[...] donec religatis post terga manibus, iniecto ceruicibus laqueo, ueste discissa seminudus in forum tractus est inter magna rerum uerborumque ludibria per totum uiae Sacrae spatium, reducto coma capite, ceu noxii solent, atque etiam mento mucrone gladii subrecto, ut uisendam praeberet faciem neue summitteret; quibusdam stercore et caeno incessentibus, aliis incendiarium et patinarium uociferantibus, parte uulgi etiam corporis uitia exprobrante. Erat enim in eo enormis proceritas, facies rubida plerumque ex uinulentia, uenter obesus, alterum femur subdebile impulsu olim quadrigae, cumauriganti Gaio ministratorem exbiberet. tandem apud Gemonias minutissimis ictibus excarnificatus atque confectus est et inde unco tractus in Tiberim. (Vit. 17.1-2) (22 $^{2}$

"Até que, de mãos atadas atrás das costas, com um laço apertado ao pescoço, de roupas rasgadas, foi arrastado para o foro, no meio de grandes ultrajes por actos e palavras, ao longo de toda a Via Sacra: puxaramlhe a

58 Com efeito, em Josefo (BJ 4.645), a iniciativa parte dos partidários dos Flávios. Também segundo Tácito (Hist. 3.69-71), são os mesmos que, comandados por Sabino, irmão de Vespasiano, decidem ocupar o Capitólio, como medida de segurança (3.69). O ataque ao Capitólio parece mais uma iniciativa acéfala dos soldados, da qual Vitélio se demarca, dizendo que já não era imperador; e chega mesmo a proteger o mensageiro, Cornélio Marcial, enviado por Flávio Sabino (3.70.4). Também para o incêndio Tácito apresenta duas versões: uma que seriam os atacantes a incendiar os tecta, e outra, mais acreditada, que seriam os próprios sitiados (3.71.4). E estes, por sua vez, são mortos contra o parecer de Vitélio (3.74.2). cf. Venini 1974: 993-994; Venini 1977: 138; Murison 1992: 169-170; Brandão 2009: 287-290; Brandão 2015: 71-84.

59 Mais um motivo para a morte de Vitélio aparecer como um castigo dos deuses, como afirma Cizek 1975: 128-129.

60 Vide Dalby 2001: 73-74.

61 Vit. 16.1. Tácito (Hist. 3.84.4) refere-se vagamente ao esconderijo como pudenda latebra, palavra que Suetónio também usa depois. Díon Cássio (65.20.2) afirma mesmo que foi mordido pelos cães. Cf. Della Corte 1967: 133. n. 85.

${ }^{62}$ Cf. Tac. Hist. 3.84.5-85. Suetónio não menciona a tentativa de um soldado da Germânia o tentar matar rapidamente (ou talvez atacar o tribuno), nem palavras de Vitélio que 
cabeça para trás pelos cabelos, como se costuma fazer aos criminosos, e ainda lhe mantiveram o queixo levantado com a ponta de um gládio, para que deixasse ver a cara e não a baixasse, enquanto alguns lhe atiravam esterco e lama, outros the gritavam os apelidos de incendiário e alarve; parte do povo até lhe censurava os defeitos do corpo. Tinha, pois, grande corpulência e rosto geralmente avermelhado da embriaguez, a barriga gorda, e uma das coxas um tanto ou quanto fraca devido ao choque de uma quadriga quando dava outrora apoio a Gaio que conduzia um carro. Finalmente, junto às Gemónias, foi dilacerado com pequeníssimos golpes e morto, e daqui foi arrastado para o Tibre com um gancho".

O biógrafo, para acentuar a degradação de Vitélio, concentra grande quantidade de informação realista, e, a partir da menção dos impropérios populares, introduz de permeio a rubrica da descrição física, caso único. Os insultos da multidão - incendiário e alarve - retomam implicitamente o tema de Nero nesta fase determinante da biografia. $\mathrm{O}$ termo incendiarius remete para a culpa do incêndio do Capitólio, que Suetónio imputa exclusivamente a Vitélio, e que este contempla no meio de um banquete. Recordemos que Vitélio já rejubilara com o incêndio do triclínio na altura da aclamação, evento infausto para outros. E o termo patinarius relembra a enorme patina que ficou associada à luxuria do imperador. Os dois adjectivos em conjunto estabelecem a conexão entre a culpa do incêndio do Capitólio e o vício da gula, por um lado, e o género de morte, por outro, a significar castigo daquelas atitudes.

Deste modo se introduz de permeio a rubrica da descrição física. Apesar de tal topos aparecer em algumas Vidas próximo da narrativa da morte (ou antes ou depois), este é o único caso em que aparece oportunamente intercalada no próprio relato. $\mathrm{O}$ retrato físico é, de facto, constituído apenas por defeitos corporais, expostos de forma burlesca e humilhante ${ }^{63}$, o que é significativo dada a relação entre físico e carácter em Suetónio. Os uitia corporis são manifestação das manchas morais. Neste caso, é clara a ligação entre a corpulência, o rosto vermelho, a barriga proeminente e os excessos de bebida e comida ${ }^{64}$. Assim, a execução pública de Vitélio transformase também no castigo da sua gula. Nesta narrativa final estão implícitos os excessos da mesa e as suas consequências nefastas a nível físico, moral e político: a degradação do imperador, e por consequência do Estado que tutela, está intimamente ligada aos hábitos (mores) dele.

lhe daria alguma dignidade: aos insultos de um tribuno responde que, apesar de tudo, fora seu imperator (cf. D.C. 65.21.2). Tácito censura a volubilidade da multidão: Et uolgus eadem prauitate insectabatur interfectum qua fouerat uiuentem. Vide Murison 1992: 173; Martin 1991: 380-385.

$63 \quad$ Vide Newbold 1984: 120.

64 Vide Martin 1991: 215-216. 
Depois da descrição física, seguese a execução junto às Gemónias, o local destinado aos mais vis criminosos. A derradeira humilhação foi ser arrastado com um gancho para o Tibre, o maior insulto que se podia fazer a um condenado morto: era o castigo dos tiranos - o castigo que os cesaricidas tinham destinado para o cadáver de César, e que o povo chegara a propor para o corpo de Tibério. Esta é a morte mais humilhante das Vidas dos Césares, em oposição radical à dignidade da morte de Otão. Para Cizek (1975: 129), a morte ignóbil de Vitélio é o ponto de partida para a descrição da vida odiosa que Suetónio nos oferece deste imperador; esta morte faculta ao biógrafo o meio, e mesmo a obrigação, de o inculpar constantemente e de o tornar desprezível.

O biógrafo parece sugerir que se trata também de um castigo dos deuses ${ }^{65}$, o que é coerente com todas as anteriores atitudes ímpias ${ }^{66}$, onde o destino também tem um papel importante, como patenteia o facto de a biografia terminar com a revelação do significado do presságio do galo em Vien ${ }^{67}$. Ora o destino e o carácter andam em Suetónio amiúde associados. O triclínio em chamas na altura da aclamação, o presságio que Vitélio procura esconjurar com palavras optimistas, já prenunciava o fim violento da elevação da gula à púrpura imperial.

\section{Considerações finais}

O objectivo da biografia é precisamente revelar os mores, os elementos definidores do carácter, através da discrição das acções e palavras do biografado. É claro que Suetónio usa o vicío da gula como um elemento fortemente estruturante desta Vida e aglutinador de outros vícios habituais da retórica contra a tirania (crueldade, impiedade, etc. ${ }^{68}$. Os dados proviriam das fontes; eram informações que corriam, mas Suetónio distorce-os na organização que lhes dá em função de objectivos éticos. O Vitélio de Suetónio é um produto

65 Assim pensa Cizek 1975: 125-130. Tácito, pelo contrário, não associa a morte de Vitélio a nenhum presságio divino.

66 Espoliou os templos durante os cargos administrativos, matou o próprio filho, proferiu palavras ímpias e bebeu em presença de cadáveres de cidadãos, matou a própria mãe, assumiu o pontificado máximo num dia infausto, não resistia a retirar a comida do fogo durante os sacrifícios, banqueteouse ao contemplar o incêndio no templo de Júpiter Máximo, decidiu depositar o punhal no templo da Concórdia e depois conservouo.

67 Trata-se do galo saltara para o ombro e para a cabeça de Vitélio (9). Diz o biógrafo que não se enganaram os que disseram que cairia às mãos de um gaulês, pois foi derrrotado por António Primo, que nascera em Tolosa e tivera na infância a alcunha de Beccus ('bico de galo'). Vit. 18. Para o biógrafo é mais importante este pormenor do que a batalha de Cremona (não mencionada), onde António Primo foi vencedor. De resto, este sétimo livro começa e termina com presságios onde as aves (galináceos) têm papel relevante, o que revela a importância destes auspícios na história romana. Vide Gascou 1984: 358-359; Power 2014: 61-62.

68 Vide Brandão 2008: 115-137. 
da hostilidade do biógrafo, da propaganda dos Flávios e da influência e generalização dos efeitos do vício da gula sobre os outros aspectos da vida, desde os antepassados até à morte. $\mathrm{O}$ ventre tem um valor determinante na concepção da Vida. A sentença foi dada por Galba: Vitélio vive para comer. Mas, paradoxalmente, na conjuntura da crise que sucedeu à morte de Nero, foi o ventre que, através de uma nomeação displicente, por parecer inofensivo, lhe obteve o poder e o apoio dos soldados, por se mostrar esbanjador. Foi o ventre que determinou a forma de governo. $\mathrm{E}$ foi o ventre que em última análise o conduziu à morte. A moralidade, o fim implícito da biografia, é clara.

A inversão, que leva a colocar o arbítrio do ventre à cabeça do Império, corresponde a um tempo de desregramento moral, um parêntese dominado por guerras civis e subversão da ordem estabelecida. Como diz Tácito (Hist. 1.4.2), foi revelado um segredo do império: os exércitos das províncias descobriram que podiam criar eles os imperadores; e os membros lançaram-se sobre a cabeça - Roma. Tal acção resultou no domínio dos impulsos rudes e irracionais em colisão uns com os outros, que se materializaram no célere desfile em Roma de quatro imperadores, como actores num palco, como salienta Plutarco (Galb. 1.4-9). O restabelecimento da ordem implica moderação em vários domínios, incluindo o da comida. O sucessor de Vitélio, Vespasiano, com a sua austeridade de cariz militar representa para o biógrafo a restauração do equilíbrio político e moral.

\section{REFERENCIAS}

André, J. (1981), L'alimentation et la cuisine à Rome, Les Belles Lettres, Paris.

Brandão, J. L. L. (2007), “Cómodo: outro Calígula, outro Nero”, Humanitas 59: 133-145.

Brandão, J. L. L. (2009), Máscaras dos Césares. Teatro e moralidade nas Vidas suetonianas, Classica Digitalia, Coimbra.

Brandão,J. L. L. (2008), “'Tirano ao tibre!' Estereótipos de tirania nas Vidas dos Césares de Suetónio", Humanitas 60: 115-137.

Brandão, J. L. L. (2015), "Páginas de Suetónio: a morte ignóbil de Vitélio", Boletim de Estudos Clássicos 60: 71-84.

Cizek, E. (1975), "La mort de Vitellius dans les Vies des douze Césars de Suétone”, REA 77: $125-130$.

Cizek, E. (1977), Structure et idéologie dans les Vies des douze Césars de Suétone, Les Belles Lettres, Paris.

D’Arms,J.H. (2004), “The culinary reality of Rome. Upper-class convivia: integrating texts and images", Comparative Studies in Society and History 46.3: 428-450. (artigo póstumo).

Dalby, A. (2001), "Dining with the Caesars", in H. Walker (ed.), Food and the Memory. Proceedings of the Oxford Symposium on Food and Cookery 2000, Prospect Books, Trowbridge, $62-88$. 
Damon, C. (2014), "Suetonius the ventriloquist", in T. Power, R. K. Gibson (eds.), Suetonius the Biographer, Oxford University Press, Oxford, 38-57.

Della Corte, F. (1967), Svetonio eques Romanus, Firenze, La Nuova Italia.

Dunkle, J. R. (1971), “The rethorical tyrant in Roman Historiography: Sallust, Livy and Tacitus", $C W 65:$ 12-20.

Gascou, J. (1984), Suétone historien, de Boccard, Paris.

Leary, T. J. (2001), The Xenia. Text with introduction and commentary, Duckworth, London.

Murison, Ch. L. (1992), Suetonius Galba, Otho, Vitellius, Edited with introdution and notes, Bristol Classical Press, London.

Murison (1987), “Tiberius, Vitellius and the spintriae”, $A H B$ 1: 97-99.

Newbold, R. F. (1984), “Suetonius' boundaries”, Latomus 43: 118-132.

Ornellas e Castro, I. (2011), De la table des dieux à la table des hommes: la symbolique de l'alimentation dans l'Antiquité, L'Harmattan, Paris.

Poulle (1997), “Les poignards de l'année 68-69”, RPh 71: 243-252.

Power, T. (2014), “The endings of Suetonius Caesars”, in T. Power, R. K. Gibson (eds.), Suetonius the Biographer, Oxford University Press, Oxford, 58-77.

Tabacco, R. (1985), "Il tiranno nelle declamazioni di scuola in lingua latina”, in Memorie della Accademia delle Scienze Morali, Storiche e Filologiche di Torino II, Classe di Scienze Morali, Storiche e Filologiche, serie V, vol. 9, Torino, 1-141.

Venini, P. (1974), "Sulle Vite suetoniane di Galba, Otone e Vitellio”, RIL 108: 991-1014.

Venini, P. (1977), C. Svetonio Tranquillo. Vite di Galba, Ottone, Vitellio, Con comm., Paravia, Torino. 
(Página deixada propositadamente em branco) 